\title{
Application of Films Based on Chitosan and Xanthan Gum in Refrigerated Fish Conservation
}

\author{
Maria de Morais Lima ${ }^{1 *}$ \\ https://orcid.org/0000-0001-7865-1792 \\ Lucia Cesar Carneiro' \\ https://orcid.org/0000-0002-8336-4496 \\ Mírian Ribeiro Galvão Machado² \\ https://orcid.org/0000-0001-7505-7659
}

\author{
Elessandra da Rosa Zavareze ${ }^{1}$ \\ https://orcid.org/0000-0001-6227-3977 \\ Carlos Prentice ${ }^{3}$ \\ https://orcid.org/0000-0003-4679-3870
}

\author{
Angelita da Silveira Moreira ${ }^{1}$ \\ https://orcid.org/0000-0001-8711-6521
}

\author{
Alvaro Renato Guerra Dias ${ }^{1}$ \\ https://orcid.org/0000-0001-5171-1812
}

${ }^{1}$ Federal University of Pelotas, College of Agronomy Eliseu Maciel, Department of Science and Technology Agroindustrial, Pelotas, Rio Grande do Sul, Brazil; ${ }^{2}$ Federal University of Pelotas, Center for Chemical, Pharmaceutical and Food Sciences, Pelotas, Rio Grande do Sul, Brazil; ${ }^{3}$ Federal University of Rio Grande, School of Chemistry and Food, Rio Grande, Rio Grande do Sul, Brazil.

Received: 2019.01.27; Accepted: 2020.07.27.

*Correspondence: demoraislima@hotmail.com; Tel./Fax: +55 5332757284

\section{HIGHLIGHTS}

- Chitosan and xanthan gum based films provided improvements in chilled fish fillets preservation.

- The films were efficient in inhibiting Staphylococcus, Salmonella and coliforms growth at $45^{\circ} \mathrm{C}$.

- The films with the highest content of xanthan gum tended to present the best results.

\begin{abstract}
This research aims to determine the efficiency of chitosan and xanthan gum films in conservation of croaker fillets kept in refrigeration for 9 days. Proximal composition, loss of mass, color, $\mathrm{pH}, \mathrm{TVB}-\mathrm{N}$ (Total Volatile Bases) and microbiological profile were assessed. The films were prepared with chitosan and xanthan gum in varying mass proportions 100:0, m:m (C100XG0); 60:40, m:m (C60XG40); 50:50, m:m (C50XG50). They presented the respective values for moisture content, water solubility, thickness and water vapor permeability: 24.59\%, 19.50\%, $0.086 \mathrm{~mm}$ and $11.45 \mathrm{gm}^{-1} . \mathrm{s}^{-1} . \mathrm{Pa}^{-1}$ for C100XG0; $24.58 \% ; 20.27 \%, 0.091$ $\mathrm{mm}$ and $10.41 \mathrm{gm}^{-1} \cdot \mathrm{s}^{-1} \cdot \mathrm{Pa}^{-1}$ for C60XG40; 22.11\%, 22.06\%, $0.089 \mathrm{~mm}$ and $10.68 \mathrm{gm}^{-1} \cdot \mathrm{s}^{-1} \cdot \mathrm{Pa}^{-1}$ forC50XG50.The films were made in small bags format capable to hold about $20 \mathrm{~g}$ of fish fillets. A control sample was prepared in parallel, using polyethylene bags under the same storage conditions. The results showed that the chitosan films combined with xanthan gum had excellent antimicrobial properties, capable of preserving the quality of chilled fish fillets during the studied period, since it inhibited the growth of Staphylococcus coagulase-positive, Salmonella spp and coliforms at $45^{\circ} \mathrm{C}$. Mass loss of the croaker fillets was not significantly affected by xanthan gum addition to the films. On the other hand, xanthan gum addition affected $\mathrm{pH}$ and color parameters of the corvina fillets. It was also verified that the combination of these two polymers promoted the reduction of N-BVT, being the C50XG50 film that presented the best response.
\end{abstract}

Keywords: chitosan; xanthan gum; film; fish; antimicrobial properties. 


\section{INTRODUCTION}

Active packaging derived from natural sources has aroused industries and researchers` interest, since, besides providing protection, security and good appearance to food, it showed to be ecologically correct [1]. Active packaging systems are based on incorporation of antimicrobial, antioxidant, among others properties substances, in order to control the undesirable variations in food quality [2].

Chitosan is a linear polysaccharide consisting of units of 2 -amino-2-deoxy- $\beta$ - $(1,4)$-D-glicosamina and 2 -acetamido-2-deoxy- $\beta$ - (1,4) -D-glucosamine, obtained by chitin deacetylation, which is the second most abundant polysaccharide found in nature after cellulose. It is considered non-toxic, biocompatible, biodegradable [3] and displays antimicrobial properties against some Gram-positive bacteria, Gram-negative bacteria, yeasts and molds [4,5]. Although chitosan is cited in literature as one of the great potential polymers in biodegradable packages usage, it shows some disadvantages, such as low mechanical strength, high solubility and water vapor permeability. One way of improving these properties is based on mixing chitosan with other polymers [6] such as xanthan gum, starch, cellulose and protein. Xanthan gum is a safe biodegradable product capable of forming a continuous, stable and cohesive matrix with physical and chemical uniform properties, promoting, as well, mechanical strength improvements when mixed with other polymers $[7,8]$.

There are few reports on films based on chitosan and xanthan gum in literature, none of them considering combined application of those two polymers for life extension of refrigerated fish [9, 10]. Croaker (Micropogonias furnieri) is economically considered one of the important fish species. It is abundantly found in the Atlantic Ocean (Caribbean to Argentina) [11]. The usage of chitosan based, antimicrobial properties packaging on this fish, may be an option to preservation and shelf life extension. Thus, the objective of this research was to verify the effects of chitosan and xanthan gum film packages in conservation of refrigerated packed croaker fillets for nine days.

\section{MATERIALS AND METHODS}

\section{Material}

The newly captured croaker (Micropogonias furnieri) was acquired directly from the fishermen of colony Z3 location - city of Pelotas - RS, Brazil. Chitosan was obtained from Polymar Ciência e Nutrição $S / A$ company, city of Fortaleza-CE - Brazil, with the following characteristics: grain size of 80 mesh, bulk density of $0.36 \mathrm{~g} / \mathrm{mL}, \mathrm{pH} 8.1$, total ash $09 \%$, viscosity of $199.5 \mathrm{cps}$ at $20^{\circ} \mathrm{C}$ and deacetylation degree of $86.7 \%$. Xanthan gum was donated for CP Kelco Brazil S.A Company, from Limeira - SP, Brazil, with the following characteristics: $180 \mu \mathrm{m}$ particle size, $\mathrm{pH} 6.3$, pyruvate content $9.35 \%$, acetyl content $6,2 \%$ and $11 \%$ moisture. All reagents used were of analytical grade.

\section{Preparation of the films}

The films were prepared using the casting technique, according to the methodology described by AraujoFarro and coauthors [12] with some modifications. Films were prepared with chitosan and xanthan gum in varying weight ratios of 100/0 (C100XG0); 60/40 (C60XG40); 50/50 (C50XG50). All solutions were prepared using $0.75 \%$ chitosan and $0.75 \%$ xanthan gum (w/v) except 100/0 (chitosan 1.5\%, w/v). Xanthan gum solutions were prepared by slowly adding the powder in $50 \mathrm{~mL}$ of distilled water under constant stirring with a magnetic stirrer at room temperature for $12 \mathrm{~h}$. The chitosan powder was dispersed in $50 \mathrm{~mL}$ distilled water containing $1 \%(\mathrm{v} / \mathrm{v})$ acetic acid with gentle shaking at room temperature until complete dissolution. Xanthan gum and chitosan dispersions were mixed, added glycerol (Synth $\AA$ ) at concentration $0.30 \mathrm{~g}$ of glycerol/polymer g. Afterwards dispersion was subjected to agitation in Ultra-Turrax (Tecnal, Turratec TE102) at $20,000 \mathrm{rpm}$ for $10 \mathrm{~min}$ to complete homogenization. Then, the filmogenic solutions were scattered $(25 \mathrm{~g})$ in Petri dishes of $9 \mathrm{~cm}$ in diameter each, so they were placed in an oven with air circulation at $38^{\circ} \mathrm{C}$ for $18 \mathrm{~h}$ (model B5AFD, DeLeo). After drying, the films were properly stored for 48 hours until the beginning of testing (at room temperature).

\section{Samples preparation}

Newly collected fish were boxed with ice cubes in an isothermal box and right afterwards transported to Federal University of Pelotas, where they were washed, gutted and filleted. The fillets were packaged in biodegradable packaging (derived from the films), made as square bags with dimensions of approximately $7 \times 7 \mathrm{~cm}$. The packages were sealed with a Sulpack bench sealer, model SM 300 Light, of continuous 
temperature. The films were prepared in small bags format with capacity to hold about $20 \mathrm{~g}$ of fish fillets. Forty samples of fish bags were prepared for each treatment. Thus, each sample packed with film was placed inside a petri dish. The petri dish containing the samples were stored under refrigeration at $4 \pm 1^{\circ} \mathrm{C}$ for nine days. A control sample was prepared in parallel, under the same conditions using polyethylene bags. The samples were evaluated on alternate days for nine days (1st, 3rd, 5th, 7th and 9th days), except for the chemical composition (first day only), color and microbiological analyses (performed on the first and last day of analyses) - as described in the items below.

\section{Samples characterization}

\section{Proximate composition}

The proximate composition of the raw material was evaluated in accordance with AOAC methodology [13]. The moisture content was determined in oven at $105^{\circ} \mathrm{C}$ to constant weight (gravimetric method $\mathrm{N}^{\circ}$. 950.46); protein content was determined by quantification of sample total nitrogen applying Kjeldahl method, using conversion factor of 6.25 (Kjeldahl method $\mathrm{N}^{\circ}$. 928.08); lipid content was obtained by Soxhlet method (Soxhlet method $N^{\circ}$. 960.39) and ash content was determined in muffle furnace at 500-600 (gravimetric method $\mathrm{N}^{\circ} .920$ 153). All analyzes were performed in triplicate.

\section{Mass loss}

Mass loss was obtained from the difference between the initial weight of the packed fillets and the weight obtained at the end of each storage period. The results were expressed in percentage of weight loss (Equation 1).

$$
\text { Mass loss }(\%)=\frac{m_{i}-m_{f}}{m_{f}}
$$

Where $m i$ is the initial mass and $m f$ is the final mass.

\section{Color}

The croaker fillets instrumental color parameters were evaluated at initial time and ending of storage period using a colorimeter (Minolta Chromometer, CR 300) CIE system $\left(\mathrm{L}^{*} \mathrm{a}^{*} \mathrm{~b}^{*}\right)$.

\section{Determination of $\mathrm{pH}$}

$\mathrm{pH}$ analysis of croaker fillets were determined according to the AOAC [13], where $10 \mathrm{~g}$ of crushed fish were homogenized with $100 \mathrm{~mL}$ of distilled water.

\section{Determination of the total volatile basic nitrogen (TVB-N)}

Volatile bases in the croaker fillets were determined according to the AOAC [14] methodology. The TVB$\mathrm{N}$ calculation (mg N/100 g) was performed according to Equation 2.

$$
\text { TVB- } N=\frac{\left(\mathrm{VHCl}_{\text {spent }}-\mathrm{VHCl}_{\text {white }}\right)^{*} \mathrm{M}_{\text {acid }}{ }^{*} 14,01}{\mathrm{~W}}
$$

Where $\mathrm{VHCl}_{\text {spent }}$ is $\mathrm{HCL}$ spent volume on sample titling $(\mathrm{mL})$; $\mathrm{VHCl}_{\text {white }}$ is $\mathrm{HCl}$ volume spent on white titration ( $\mathrm{mL}$ ); $\mathrm{M}_{\text {acid }}$ is HCL molarity; $\mathrm{W}$ is sample weight $(\mathrm{g})$.

\section{Microbiological analysis}

The croaker fillets with and without chitosan and xanthan gum based film were evaluated for detecting coagulase positive Staphylococcus, Salmonella and coliforms at $45{ }^{\circ} \mathrm{C}$, according to the methodology recommended by APHA [15].

\section{Statistical analysis}

The analyses were performed in triplicate; the results were analyzed statistically using variance analysis (ANOVA) and the Tukey test at a $5 \%$ significance level. 


\section{RESULTS AND DISCUSSION}

\section{Chemical composition of the croaker fillets}

The chemical composition (wet basis) of the croaker fillets were $75.85 \pm 0.55 \%$ moisture; $18.71 \pm 0.21 \%$ protein; $4.03 \pm 0.48 \%$ of lipids and $1.00 \% \pm 0.55$ of ash. Fish chemical composition may vary depending on muscle type, sex, age, season, habitat and diet among other factors [16]. Curcho and coauthors [17] evaluated croaker sample chemical composition found $77.9 \%$ moisture, $19.6 \%$ protein, $1.06 \%$ ash and $1.46 \%$ lipids. Luzia and coauthors [16] studying the profile of croaker lipid, found different lipid levels for each time of year $-0.6 \%$ for the summer and $3.29 \%$ for the winter.

\section{Mass loss}

Mass loss values of croaker fillets packed with and without coatings based on chitosan and xanthan gum stored at $4 \pm 1{ }^{\circ} \mathrm{C}$ for nine days are shown in Table 1 .

Table 1. Mass loss values of croaker fillets packed with and without chitosan and xanthan gum based coatings stored at $4 \pm 1^{\circ} \mathrm{C}$ for 9 days.

\begin{tabular}{lcccc} 
Films $^{\mathrm{a}}$ & \multicolumn{4}{c}{ Mass loss $(\%)$} \\
\cline { 2 - 5 } CONTROL & 3rd day & 5 th day & 7 th day & 9 th day \\
C100XG0 & $0.11 \pm 0.19 \mathrm{bB}$ & $0.115 \pm 0.02 \mathrm{bB}$ & $0.19 \pm 0.03 \mathrm{bA}$ & $0.24 \pm 0.02 \mathrm{bA}$ \\
C60XG40 & $1.46 \pm 0.31 \mathrm{aC}$ & $2.18 \pm 0.51 \mathrm{aBC}$ & $3.68 \pm 0.34 \mathrm{aAB}$ & $4.01 \pm 0.64 \mathrm{aA}$ \\
C50XG50 & $1.32 \pm 0.47 \mathrm{aB}$ & $1.96 \pm 0.56 \mathrm{aAB}$ & $3.12 \pm 0.73 \mathrm{aA}$ & $3.58 \pm 0.79 \mathrm{aA}$ \\
& $1.60 \pm 0.61 \mathrm{aB}$ & $2.23 \pm 0.75 \mathrm{aAB}$ & $3.03 \pm 0.86 \mathrm{aA}$ & $3.42 \pm 0.88 \mathrm{aA}$
\end{tabular}

aDifferent lowercase letters in the same column and different uppercase letters on the same line differ with eachother by Tukey's test $(p \leq 0.05)$.

According to Table 1, increased mass loss during storage for all treatments was observed. The loss was significantly lower in the control treatment (polyethylene packaging). Among the other treatments, there were no significant differences $(p \leq 0.05)$, so the addition of xanthan gum did not improve the performance of the films. The highest losses were observed from the seventh day of storage on.

Analyzes regarding the structural, thermal, physical, mechanical and barrier properties of the films were carried out in one of our previous studies [10]. However, it was concluded that the addition of xanthan gum did not reduce the moisture content, solubility, water vapor permeability of the films, but significantly altered the thermal, mechanical, physical, optical and structural properties of the films. Thus, xanthan gum additioning to the films did not significantly cause changes in solubility and water vapor permeability values of the films, nor mass loss of the packaged fish fillets.

Soares and coauthors [18] studying the effect of glaze and chitosan-based coating on frozen salmon preservation, verified that the mass loss did not present significant difference during storage, except in the last time studied, when the mass value was statistically different from the first two initial times. Although very small, these values show a growing trend over the entire storage period. Johnston and coauthors [19] report that many factors can influence mass loss, such as temperature, temperature change, moisture, shape and size of the product. Soares and coauthors [20] report that proper control of storage temperature is the key factor to get low mass loss values.

\section{pH of croaker fillets}

$\mathrm{pH}$ values of croaker fillets packed with and without the films based on chitosan and xanthan gum stored at $4 \pm 1{ }^{\circ} \mathrm{C}$ for 9 days are shown in Figure 1 . 


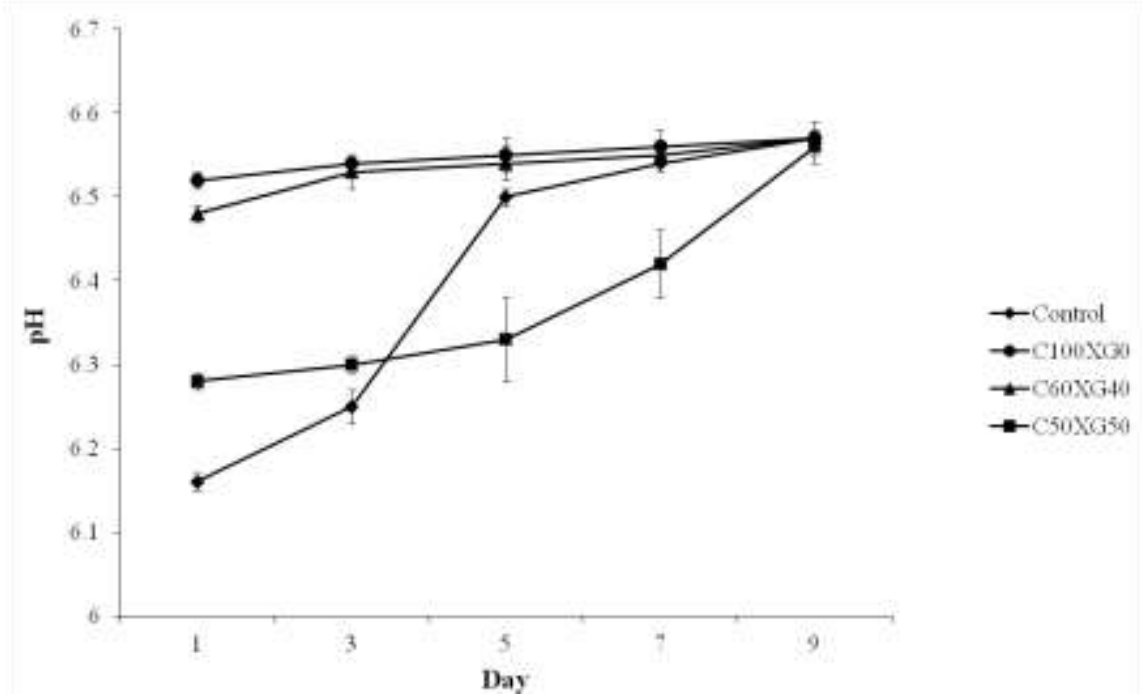

Figure 1. Croaker fillets $\mathrm{pH}$ variation packed with and without the films based on chitosan and xanthan gum stored at $4 \pm 1{ }^{\circ} \mathrm{C}$ for 9 days.

It was observed (Figure 1) that the coatings influenced the $\mathrm{pH}$ values since the first day of storage, showing significant differences between the treatments. Similar results were observed by Kilincceker and coauthors [21] when studying the coating effect on frozen fish fillets. Increased pH values were observed during the storage period in all treatments. Borges and coauthors [22] when studying the shelf life of Pacus (Piaractus mesopotamicus) stored on ice, also verified that behavior. Chaijan and coauthors [23] report that the $\mathrm{pH}$ increasing is related to protein degradation, occuring the production of substances such as ammonia and other amines.

According with brazilian legislation, fish meat $\mathrm{pH}$ is considered suitable for consumption when it is less than 6.8 [24]. In this sense, all treatments showed $\mathrm{pH}$ fit for consumption. Fan and coauthors [25] found that the lower the $\mathrm{pH}$ the better the microbial inhibition and, consequently, the longer the life span of fish samples. When inquiring the effect of chitosan coating on white shrimp preservation during partially frozen storage, Wu [26] found that the group coated with chitosan showed initial pH value higher than the control group, but ten days after, the control group began to show higher $\mathrm{pH}$ values than the chitosan coated group.

\section{Color of the croaker fillets}

The color parameters were recorded to evaluate the color changes of croaker fillets surfaces when packed with and without chitosan and xanthan gum based film (Table 2 and Figure 2).

Table 2. Croaker fillets color packed with and without the chitosan and xanthan gum based film, stored at $4 \pm 1{ }^{\circ} \mathrm{C}$ for 9 days.

\begin{tabular}{|c|c|c|c|c|c|c|c|c|}
\hline \multirow[t]{2}{*}{ Films ${ }^{a}$} & \multicolumn{4}{|c|}{ Color parameters 1st day } & \multicolumn{4}{|c|}{ Color parameters 9th day } \\
\hline & $L^{*}$ & $a^{*}$ & & $b^{*}$ & & $\mathrm{~L}^{*}$ & $a^{*}$ & $b^{*}$ \\
\hline$\checkmark$ & 47. & 3.0 & -2.07 & \pm 0 & & $\pm 0.21 \mathrm{aA}$ & $B$ & -0.4 \\
\hline C1 & $47.20 \pm 0.55 \mathrm{aB}$ & $1.50 \pm 0.48 \mathrm{bA}$ & 4.74 & $\pm 0.18 \mathrm{aB}$ & 52.27 & $61 \mathrm{aA}$ & $-1.32 \pm c$ & $6 a A$ \\
\hline C60XG40 & $44.61 \pm 0.43 \mathrm{bB}$ & $2.35 \pm 0.46 \mathrm{abA}$ & 1.98 & \pm 0.8 & 46.34 & $\pm 0.36 \mathrm{bA}$ & $1.64+0.60 \mathrm{aA}$ & $1.40 \pm 0.50 \mathrm{bA}$ \\
\hline C50XG50 & $44.9 \pm 0.08 \mathrm{bB}$ & $2.52 \pm 0.02 \mathrm{aA}$ & 1.27 & $\pm 0.03 \mathrm{bA}$ & 46.82 & $\pm 0.02 \mathrm{bA}$ & $1.78 \pm 0.02 \mathrm{aB}$ & $1.23 \pm 0.01 \mathrm{bA}$ \\
\hline
\end{tabular}

aDifferent lowercase letters in the same column and different uppercase letters on the same line differ with eachother by Tukey's test $(p \leq 0.05)$.

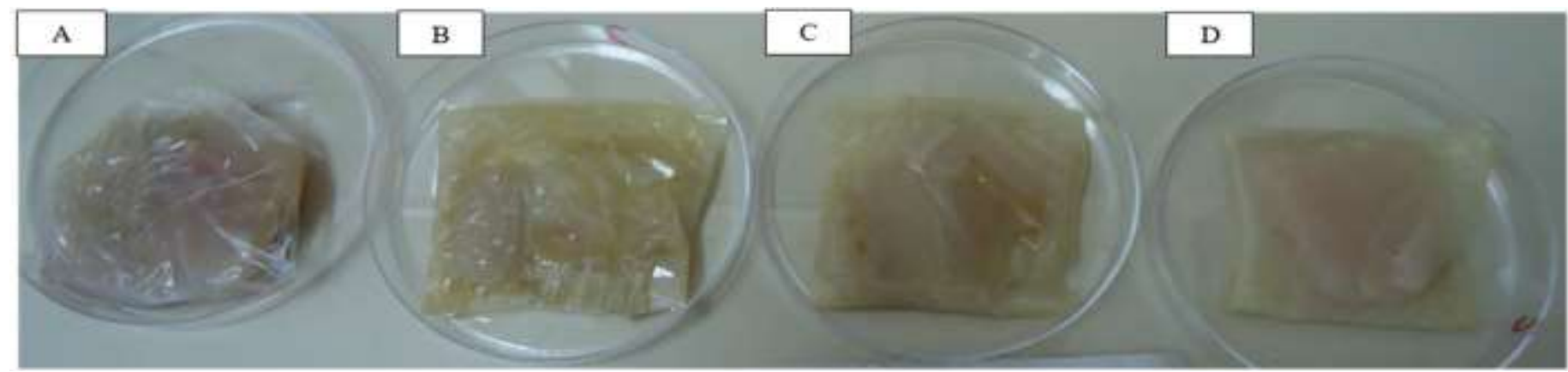

Figure 2. Croaker fillets during storage (9th day) A: CONTROL; B: C100XG0; C: C60XG40; e D: C50XG50. 
The color measurements were carried out in the first and ninth day of storage. They were conducted directly into the muscle without coatings interference, since they were removed at analyses moment, the samples were the same ones in the first and last day of storage in order to avoid any discrepancies as croaker muscle does not have color uniformity.

According to Table 2, there was parameter $L^{*}$ (lightness) increase in all treatments, while the treatment C100XG0 obtained the highest percentage $(5.07 \%)$ compared to the last day of storage. Based on Hunter diagram, the higher the $L^{*}$ value (closer to 100) the paler the analyzed muscle will be. Solval and coauthors [27] evaluating chitosan nanoparticles as glazing material for frozen shrimp $\left(-21^{\circ} \mathrm{C}\right.$ for thirty days) have also found $L^{*}$ parameter increase during storage, although a not significant one. Chandrasekaran [28] mentions that the color fading is one of the most important changes in fish quality during storage. Moreover, lipid oxidation has been linked to color degradation during storage [29].

By the end of study all treatments revealed lower intensity for parameter $a^{*}$. Shrimp waste enriched chitosan coatings for the preservation of shrimp were studied by Arancibia and coauthors [30].Those authors had observed increased parameter $a^{*}$ during the refrigerated storage14 days period.

Regarding parameter $b^{*}$, significant variations were observed $(p<0.05)$ from $1^{\text {st }}$ to $9^{\text {th }}$ day only for C100XG0 treatment. It was also the only one to a higher account for this parameter over the storage time. That possibly can be attributed to yellow color of pure chitosan coating which was probably transferred over time to croaker muscle. Rodriguez-Turienzo and coauthors [31] report decrease for $b^{*}$ parameter during the analysis period, when analysing milk protein coatings on frozen atlantic salmon fillets. Cortez-Vega [32] reported that $a^{*}$ and $b^{*}$ parameters decreasing values during the storage period may indicate oxidative darkening.

\section{TVB-N of the croaker fillets}

TVB-N value of croaker fillets packed with and without the films based on chitosan and xanthan gum can be seen in Table 3.

Table 3. TVB-N values of croaker fillets packed with and without the films based on chitosan and xanthan gum stored at $4 \pm 1^{\circ} \mathrm{C}$ for 9 days.

\begin{tabular}{cccccc}
\hline \multirow{2}{*}{ Films $^{\mathrm{a}}$} & \multicolumn{5}{c}{ Total volatile basic nitrogen (TVB-N) } \\
\cline { 2 - 6 } & 1st day & 3rd day & 5th day & 7th day & 9th day \\
\hline CONTROL & $6.54 \pm 0.32 \mathrm{aD}$ & $7.66 \pm 0.32 \mathrm{aC}$ & $10.08 \pm 0.00 \mathrm{aB}$ & $10.86 \pm 0.32 \mathrm{aB}$ & $12.33 \pm 0.56 \mathrm{aA}$ \\
C100XG0 & $5.97 \pm 0.32 \mathrm{aB}$ & $6.91 \pm 0.32 \mathrm{aB}$ & $9.71 \pm 0.65 \mathrm{aA}$ & $10.27 \pm 0.32 \mathrm{aA}$ & $10.83 \pm 0.65 \mathrm{bA}$ \\
C60XG40 & $6.35 \pm 0.32 \mathrm{aC}$ & $7.65 \pm 0.32 \mathrm{aBC}$ & $9.15 \pm 0.85 \mathrm{aB}$ & $8.96 \pm 1.12 \mathrm{abB}$ & $10.77 \pm 0.00 \mathrm{bA}$ \\
C50XG50 & $5.97 \pm 0.32 \mathrm{aC}$ & $5.41 \pm 0.65 \mathrm{bC}$ & $9.15 \pm 0.32 \mathrm{aA}$ & $7.84 \pm 0.00 \mathrm{bB}$ & $8.41 \pm 0.56 \mathrm{cAB}$ \\
\hline
\end{tabular}

aDifferent lowercase letters in the same column and different uppercase letters on the same line differ with eachother by Tukey's test $(p \leq 0.05)$.

The TVB-N values of chilled croaker fillets at $4 \pm 1^{\circ} \mathrm{C}$ ranged from 5.97 to $12.35 \mathrm{mg}$ nitrogen per $100 \mathrm{~g}$ of muscle during the study period (Table 3 ). The control treatment showed a significant difference from the third day of storage on, while differences were observed from the fifth day of storage on in the other treatments. In this sense, TVB-N highest value was registered for the control treatmentby the end of the storage period ( $12.35 \mathrm{mgN} / 100 \mathrm{~g})$, contrapositioning to the C50XG50 treatment, with the lowest value (8.41 $\mathrm{mgN} / 100 \mathrm{~g}$ ).

According to Brazil's normative instrument for industrial inspection and animal health products (RIISPOA), $30 \mathrm{mg}$ of nitrogen per $100 \mathrm{~g}$ of muscle is the maximum acceptable rate for Total Volatile Bases (TVB-M) to be considered as fresh fish [24]. In such aspect, all treatments were considered acceptable for human consumption during the analysis period. Wu [26] in evaluation to the preservation effect of chitosan coating on white shrimp partially frozen during storage reported that chitosan coating can delay the formation of TVB-N. According to Fan and coauthors [25], TVB-N are mainly composed by ammonia and primary, secondary and tertiary amines. The method is widely used as an indicator of deterioration of muscle tissues. Increasing of TVB-N is related to the activity of the deteriorating bacteria and endogenous enzymes [33]. Ramezani and coauthos [5] found TVB-N values between 11.4 and $13.3 \mathrm{mg}$ of N/100 $\mathrm{g}$ of fishwhen evaluated fillets of silver chilled carp at $4^{\circ} \mathrm{C}$ for 12 days of storage. 


\section{Microbiological analysis}

The results concerning quantifications of total coliforms and thermotolerant coliforms of croaker fillets packed with and without chitosan and xanthan gum films are shown in Table 4.

Table 4. Most Probable Number (MPN) of Total Coliforms (CT) and Thermotolerant Coliforms (TTC) of croaker fillets packed with and without the film based on chitosan and xanthan gum, stored at $4 \pm 1^{\circ} \mathrm{C}$.

\begin{tabular}{|c|c|c|c|c|}
\hline \multirow[t]{2}{*}{ Films } & \multicolumn{2}{|c|}{$\begin{array}{l}\text { Total Coliforms (TC) } \\
\text { MPN. } g^{-1}\end{array}$} & \multicolumn{2}{|c|}{$\begin{array}{c}\text { Thermotolerant Coliforms (TTC) } \\
\text { MPN. } \mathrm{g}^{-1}\end{array}$} \\
\hline & Starting time & Final time & Starting time & Final time \\
\hline CONTROL & $1.5 \times 10^{2}$ & $1.1 \times 10^{3}$ & $1.5 \times 10^{2}$ & $>1.1 \times 10^{3}$ \\
\hline C100XG0 & 3.6 & $2.3 \times 10$ & 3.6 & $2.3 \times 10$ \\
\hline C60XG40 & $1.1 \times 10^{3}$ & $2.3 \times 10$ & $1.1 \times 10^{3}$ & 9.2 \\
\hline C50XG50 & $4.3 \times 10$ & 9.2 & $4.3 \times 10$ & 9.2 \\
\hline
\end{tabular}

According to Table 4, one can observe the presence of total and thermotolerant coliforms in all treatments and periods studied, which can be related to contamination of capture site, once the microbiota of newlycaught fish reflects the quality of water where it lives [34]. In this sense, the presence of those microorganisms may be linked to contaminated water of the Patos Lagoon, where the fish were captured. Canal and coauthors [35] found high rate of contamination by Escherichia coli when assessed surface waters of the Patos Lagoon.

According to the results, it can be observed that the C100XG0 treatment (control) showed the highest growth of microorganisms, what suggests that the use of chitosan or combinations of chitosan and xanthan gum as fish coatings inhibit the growth of the microorganisms studied (Table 4). There is no tolerable limit established in Brazilian legislation for thermotolerant coliforms in fresh fish. High levels of them detected indicate disabled sanitary conditions [36].

Gelatin-chitosan films embedded of essential oils were studied by Gómez-Estaca and coauthors [37] as an antimicrobial agent for preserving fish. The results showed that the thyme essential oil inhibited the growth of E. coli. Chen and coauthors [38] found that chitosan nanoparticles significantly reduced the growth of Escherichia coli (Gram negative) and Staphylococcus aureus (gram positive), when studying the antibacterial activity of eugenol and chitosan nanoparticles grafted with carvacrol.

The results for quantification of $S$. aureus and Salmonella detection on croaker fillets packed with and without chitosan and xanthan gum films can be seen in Table 5.

Table 5. Quantification of $S$. aureus and Salmonella detection of croaker samples packaged with and without the base film of chitosan and xanthan gum stored at $4 \pm 1^{\circ} \mathrm{C}$.

\begin{tabular}{|c|c|c|c|c|}
\hline \multirow[t]{2}{*}{ Films } & \multicolumn{2}{|c|}{$\begin{array}{c}\text { Staphylococcus aureus } \\
\left(\text { UFC. }^{-1}\right)\end{array}$} & \multicolumn{2}{|c|}{$\begin{array}{c}\text { Salmonella } \\
\text { Presence/absence in } 25 \mathrm{~g}\end{array}$} \\
\hline & Starting time & Final time & Starting time & Final time \\
\hline CONTROL & $<10$ & $1.6 \times 10^{5}$ & Absence & Absence \\
\hline C100XG0 & $<10$ & $<10$ & Absence & Absence \\
\hline C60XG40 & $<10$ & $1.2 \times 10^{5}$ & Absence & Absence \\
\hline C50XG50 & $<10$ & $<10$ & Absence & Absence \\
\hline
\end{tabular}

According to Table 5, Staphylococcus bacteria colony growth coagulase positive characteristics were found in all treatments and times. Regarding the initial time, it was observed that the treatments presented similar behavior as for the growth of that microorganism and as for the final time only the treatments C100XG0 and C50XG50 maintained the behavior of the first day. The other treatments presented a multiplication of microorganisms above the standard established by the legislation in force. Current legislation establishes a maximum of $10^{3} \mathrm{CFU} / \mathrm{g}$ coagulase positive Staphylococcus limit for fresh refrigerated fish [39]. Rao and coauthors [40] observed that chitosan films were effective against both Escherichia coli and Staphylococcus aureus, when studying chitosan and guar gum films.

This study has not detected Salmonella presence in the croaker samples with and without coating, indicating that the results meet Brazilian law criteria [39] which is the absence in $25 \mathrm{~g}$ to fish in natura colds. Lunestad and coauthors [41] report that Salmonella habitat is the intestinal tract of man and animals, the presence in fish indicates likely fecal contamination from human sources or animals. Therefore, fish caught in unpolluted waters are free from Salmonella, because this microorganism is not part of fish natural microbiota.

In literature, there are several reports on antimicrobial activity of chitosan. One of the reasons given for the antimicrobial character of the chitosan is associated with the formation of polyelectrolyte complex, since 
the amino groups having positive charges, interacts with the charged microbial cells membranes, negatively altering cellular activity and membrane permeability, resulting loss of intracellular components and the consequent microbial inhibition [42].

Van den Broek and coauthors [43] reported that the mechanism by which the chitosan acts as an antimicrobial compound is not fully elucidated, however these authors mention three cases:

a) The polycationic nature (positive charge) of chitosan that interfere with the bacterial metabolism by electrostatic stack (negative charge) on the cell surface;

b) Low molecular weight of chitosan that can enter the cell nucleus blocking DNA-RNA transcription due to the adsorption of DNA molecules;

c) Chitosan works as chelator of essential minerals.

Horn and coauthors [44] reported that chitosan and xanthan gum are polyelectrolytes with potentially ionizable groups, and when they are mixed in an aqueous solution, a complex is formed due to electrostatic attraction. The complexation reaction between chitosan and xanthan gum occurs due to interaction between opposite charges present in the biopolymer $\left(\mathrm{NH}_{3}{ }^{+}\right.$group of chitosan and xanthan gum $\mathrm{COO}^{-}$group), and due to molecular interaction between the polymer chains. The 3D network structure formed between the two polymers has an important advantage, since the complexing process increases the mechanical and chemical stability.

Microbiological analyses results in this study showed that xanthan gum addition to the chitosan films provided better or equal responses in relation to that of pure chitosan films. Lima and coauthors [10] studying the structural, thermal, physical, mechanical and barrier properties of chitosan and xanthan gum films, found that xanthan gum provided an improvement in the mechanical properties of the films, since the films containing the highest content of xanthan gum showed higher tensile strength and lower elongation. In additional, they also found that xanthan gum addition did not affect the water vapor permeability, water solubility and moisture content of films. We have not found previous studies that associate the interaction of chitosan and xanthan as an antimicrobial agent.

\section{CONCLUSION}

This study demonstrated that chitosan films combined with xanthan gum presented excellent antimicrobial properties, capable of preserving of refrigerated fish fillets during the studied period. Croaker fillets mass loss were not significantly affected by the addition of xanthan gum to the films. On the other hand, the addition of xanthan gum affected the $\mathrm{pH}$ and color parameters of croaker fillets. Reduction of TVB-N caused by the combination of those two polymers was also verified, when the C50XG50 film was the best response one. Correlating the results of the present study with those of the analyzes about the properties of the films (developed in another study), it appears that xanthan gum addition to the films did not significantly change solubility, water vapor permeability values of the films, nor the loss of mass of the packaged fish fillets. Therefore, it is believed that the positive results of this study are probably related to chitosan antimicrobial activity and the synergistic effect of these polymers. Therefore, more studies need to be carried out with quality applications of these polymers as food packaging materials, in order to evaluate their potential and disseminate these polymers benefits for food products quality.

ACKNOWLEGMENTS: The authors are grateful for xanthan gum donation by CP Kelco Brazil S.A (Limeira-SP. Brazil).

\section{REFERENCES}

1. Zemljič LF, Tkavc T, Vesel A, Šauperl O. Chitosan coatings onto polyethylene terephthalate for the development of potential active packaging material. Appl Surf Sci. 2013, 265:697-703.

2. Salgado PR, Fernández GB, Drago SR, Mauri AN. Addition of bovine plasma hydrolysates improves the antioxidant properties of soybean and sunflower protein-based films. Food Hydrocolloid. 2011, 25:1433-40.

3. Elsabee M Z, Abdou ES. Chitosan based edible films and coatings: A review Mater. Sci. Eng. 2013, 33:1819-41.

4. Chen MC, Yeh GHC, Chiang BH. Antimicrobial and physicochemical properties of methylcellulose and chitosan films containing a preservative. J. Food Process. Pres. 1996, 20:379-90.

5. Ramezani Z, Zarei M, Raminnejad N. Comparing the effectiveness of chitosan and nano chitosan coatings on the quality of refrigerated silver carp fillets. Food Control. 2015, 51:43-8.

6. Bonilla J, Fortunati E, Atares L, Chiralt A, Kenny JM. Physical, structural and antimicrobial properties of poly vinyl alcohol-chitosan biodegradable films. Food Hydrocolloid. 2014, 35:463-70 
7. Fitzpatrick P, Meadows J, Ratcliffe I, Williams PA. Control of the properties of xanthan/glucomannan mixed gels by varying xanthan fine structure. Carbohydr. Polym. 2013, 92:1018-25.

8. Veiga-Santos P, Oliveira LM, Cereda MP, Alves A J, Scamparini ARP. Mechanical properties, hydrophilicity and water activity of starch-gum films: effect of additives and deacetylated xanthan gum. Food Hydrocolloid. 2005, 19:341-9.

9. Lima MM, Bianchini D, Dias AG, Zavareze ER, Prentice C, Silveira MA. Biodegradable films based on chitosan, xanthan gum, and fish protein hydrolysate. J. Appl. Polym. Sci. 2017, 134: 1-9.

10.Lima MM, Carneiro LC, Bianchini D, Dias ARG, Zavareze ER, Prentice C, et al. Structural, thermal, physical, mechanical, and barrier properties of chitosan films with the addition of xanthan gum. J. Food Sci. 2017, 82: 698705.

11.Isaac VJ, Synopsis of biological data on the whitemouth croaker: Micropogonias furnieri (Desmarest, 1823). FAO Fisheries Synopsis, 150, 35, 1988.

12.Araujo-Farro PC, Podadera G, Sobral PJ, Menegalli FC. Development of films based on quinoa (Chenopodium quinoa, Willdenow) starch. Carbohydr. Polym. 2010, 81:839-48.

13.AOAC. Association of Official Analytical Chemists. Official methods of analysis. 15 th ed. Washington, 1990.

14.AOAC. Association of Official Analytical Chemists. Official methods of analysis. 16 th ed. Washington, 2000.

15. APHA. American Public Health Association. Compendium of Methods for the Microbiological Examination of Foods. $4^{\mathrm{a}}$ ed., Washington, 2001.

16. Luzia LA, Sampaio GR, Castellucci CM, Torres EA. The influence of season on the lipid profiles of five commercially important species of brazilian fish. Food chem. 2003, 83:93-7.

17.Curcho MRDSM, Farias LA, Baggio SR, Fonseca BC, Nascimento SMD, Bortoli MCD. Mercury and methylmercury content, fatty acids profile, and proximate composition of consumed fish in Cananéia. Rev Inst Adolfo Lutz. (Impresso). 2009, 68:442-50.

18.Soares NM, Oliveira MS, Vicente AA. Effects of glazing and chitosan-based coating application on frozen salmon preservation during six-month storage in industrial freezing chambers. LWT-Food Sci. Technol. 2015, 61:524-31.

19.Johnston WA, Nicholson FJ, Roger A, Stroud GD. Freezing and refrigerated storage in fisheries. FAO Fisheries Technical Paper 340, Food and Agriculture Organization, Rome, 1994.

20.Soares NM, Mendes TS, Vicente AAJ. Effect of chitosan-based solutions applied as edible coatings and water glazing on frozen salmon preservation-A pilot-scale study. Food Eng. 2013, 119:316-23.

21.Kilincceker O, Dogan IS, Kucukoner E. Effect of edible coatings on the quality of frozen fish fillets. LWT-Food Sci. Technol. 2009, 42:868-73.

22.Borges A, Conte-Junior CA, Franco RM, Freitas MQ. Quality Index Method (QIM) developed for pacu Piaractus mesopotamicus and determination of its shelf life. Food Res Int. 2013, 54:311-7.

23. Chaijan M, Benjakul S, Visessanguan W, Faustman C. Changes of pigments and color in sardine (Sardinella gibbosa) and mackerel (Rastrelliger kanagurta) muscle during iced storage. Food chem. 2005, 93:607-17.

24. Brasil. Ministério da Agricultura. Regulamento de Inspeção Industrial e Sanitária de Produtos de Origem Animal (RIISPOA): Decreto № 30691 de 29 de março de 1952. Seção 1- Capitulo 7 - Pescados e Derivados. Diário Oficial da União, Brasília, DF, 1952.

25. Fan W, Sun J, Chen Y, Quu J, Zhang Y, Chi Y. Effects of chitosan coating on quality and shelf life of silver carp during frozen storage. Food Chem. 2009, 115:66-70.

26. Wu S. Effect of chitosan-based edible coating on preservation of whiteshrimp during partially frozen storage. Int $J$ Biol Macromol. 2014, 65:325-8.

27.Solval KM, Rodezno LAE, Moncada M, Bankston JD, Sathivel S. Evaluation of chitosan nanoparticles as a glazing material for cryogenically frozen shrimp. LWT-Food Sci. Technol. 2014, 57:172-80.

28. Chandrasekaran, M. Methods for preprocessing and freezing of shrimps: a critical evaluation. J Food Sci Tech Mys. 1994, 31:441-52.

29.Lanari MC, Schaefer DM, Cassens RG, Scheller KK. Atmosphere and blooming time affect color and lipid stability of frozen beef from steers supplemented with vitamin E. Meat Sci.1995, 40:33-44.

30.Arancibia MY, López-Caballero ME, Gómez-Guillén MC, Montero P. Chitosan coatings enriched with active shrimp waste for shrimp preservation. Food Control. 2015, 54:259-66.

31.Rodriguez-Turienzo L, Cobos A, Moreno V, Caride A, Vieites, JM, Diaz O. Whey protein-based coatings on frozen Atlantic salmon (Salmo salar): Influence of the plasticiser and the moment of coating on quality preservation. Food Chem. 2011, 128:187-94.

32.Cortez-Vega WR, Pizato SSJTA, Prentice C. Using edible coatings from Whitemouth croaker (Micropogonias furnieri) protein isolate and organo-clay nanocomposite for improve the conservation properties of fresh-cut 'Formosa'papaya. Innov. Food Sci. \& Emerg. Technol. 2014, 22:197-202. 
33. Kyrana VR, Lougovois VP, Valsamis DS. Assessment of shelf life of maricultured gilthead sea bream (Sparus aurata) stored in ice. Int J Food Sci Tech.1997, 32:339-47.

34.Rhodes MW, Kator HOWARD. Survival of Escherichia coli and Salmonella spp. in estuarine environments. Appl Environ Microbiol. 1988, 54:2902-7.

35. Canal N, Meneghetti KL, Almeida CPD, Bastos MDR, Otton LM, Corção G. Characterization of the variable region in the class 1 integron of antimicrobial-resistant Escherichia coli isolated from surface water. Braz. J. Microbiol. 2016, 47:337-44.

36. Begum M, Ahmed ATAM, Parveen SA. Comparative microbiological assessment of five types of selected fishes collected from two different market. Adv Biol Res (Rennes). 2010, 4:259-65.

37.Gómez-Estaca J, Lacey AL, López-Caballero ME, Gómez-Guillén MC, Montero P. Biodegradable gelatin-chitosan films incorporated with essential oils as antimicrobial agents for fish preservation. Food Microbiol. 2010, 27:889-96.

38. Chen F, Shi Z, Neoh KG, Kang ET. Antioxidant and antibacterial activities of eugenol and carvacrol-grafted chitosan nanoparticles. Biotechnol. Bioeng. 2009. 104:30-9.

39.Brasil. Agência Nacional de Vigilância Sanitária. Resolução RDC № 12, de 12 de janeiro de 2001. Aprova 0 Regulamento Técnico sobre Padrões Microbiológicos para Alimentos. Diário Oficial da União. Brasília, DF, 2001.

40. Rao MS, Kanatt SR, Chawla SP, Sharma A. Chitosan and guar gum composite films: Preparation, physical, mechanical and antimicrobial properties. Carbohydr. Polym. 2010, 82:1243-7.

41.Lunestad BT, Nesse L, Lassen J, Svihus B, Nesbakken T, Fossum K, et al. Yazdankhah, S. Salmonella in fish feed; occurrence and implications for fish and human health in Norway. Aquaculture. 2007, 265:1-8.

42.Avadi MR, Sadeghi AMM, Tahzibi A, Bayati KH, Pouladzadeh M, Zohuriaan-Mehr MJ, et al. Diethylmethyl chitosan as an antimicrobial agent: synthesis, characterization and antibacterial effects. Eur. Polym. J. 2004, 40: 1355-61.

43. Van den Broek, LAM, Knoop RJ, Kappen FH Boeriu CG. Chitosan films and blends for packaging material. Carbohydr. Polym. 2015, 116:237-42.

44. Horn MM, Martins VCA, Guzzi Plepis AMG. Influence of collagen addition on the thermal and morphological properties of chitosan/xanthan hydrogels. Int J Biol Macromol. 2015, 80:225-30.

(C) 5 (5) 2020 by the authors. Submitted for possible open access publication under the terms and
conditions of the Creative Commons Attribution (CC BY NC) license
(https://creativecommons.org/licenses/by-nc/4.0/). 